\title{
MODEL PEMBELAJARAN LIMA DOMAIN SAINS DENGAN PENDEKATAN KONTEKSTUAL UNTUK MENGEMBANGKAN PEMBELAJARAN BERMAKNA
}

\author{
Dadan Rosana \\ Pendidikan Fisika FMIPA UNY \\ haidaraufa@yahoo.co.id
}

\begin{abstract}
Abstrak
Penelitian ini bertujuan untuk mengembangkan Model Pembelajaran Lima Domain Sains (MP5DS) dengan pendekatan kontekstual berlandaskan teori konstruktivisme untuk menghasilkan pembelajaran bermakna, melalui tahapan; (1) pengembangan perangkat pembelajaran dan sumber belajar (2) pengujian hubungan antar variabel, serta MP5DS dengan variabel yang mempengaruhinya. Metode penelitian mengggunakan penelitian dan pengembangan model spiral. Teknik analisis yang digunakan adalah analisis jalur dan model persamaan struktural menggunakan AMOS 6.0. Hasil penelitian ini menunjukkan: (1) prototipe perangkat pembelajaran dan prosedur implementasi MP5DS untuk pembelajaran sains, (2) terdapat pengaruh langsung yang positif dan signifikan maupun tidak langsung antar variabel kognitif, afektif, proses, aplikasi dan kreativitas, (3) pencapaian nilai tes kognitif pada kategori tinggi $(73,11 \%)$, nilai sikap cukup baik $(58 \%)$, nilai proses tinggi $(63,31 \%)$, nilai aplikasi tinggi $(61,93 \%)$ dan nilai kreativitas masih rendah $(39,41 \%)$, serta (4) MP5DS dipengaruhi oleh lingkungan psikososial pembelajaran sains dan kompetensi guru. Variabel lingkungan psikososial pembelajaran sains memiliki pengaruh langsung positif dan signifikan (faktor bobot $=0,60, \mathrm{cr}=11,490$, dan $\mathrm{p}<0,000 \mid$ ), tetapi variabel kompetensi guru pengaruhnya tidak signifikan (faktor bobot $=0,34, \mathrm{cr}=11,490$, dan $\mathrm{p}<0,000 \mid$ ).

Kata kunci: MP5DS, kontekstual, pembelajaran bermakna




\title{
INSTRUCTIONAL MODEL OF FIVE DOMAINS OF SCIENCE USING CONTEXTUAL APPROACH TO DEVELOP MEANINGFUL INSTRUCTION
}

\author{
Dadan Rosana \\ Pendidikan Fisika FMIPA UNY \\ haidaraufa@yahoo.co.id
}

\begin{abstract}
The goal of the research is to develop an Instructional Model of Five Domains of Science (IMFDS) with designed by employing contextual approach based on constructivism theory to establish meaningful instruction through: (1) develop and implement the learning tools and resources, (2) examine the relation pattern among the variables. The method is Research and Development (R\&D) consisting of descriptive, evaluative, and experimental methods. The model is spiral method consisting of 5 development stages, i.e. defining, designing, demonstrating, developing, and delivering. The results are: (1) the instructional model meets the science learning and teaching relevance criteria for students, (2) there is an inter-related correlation among variables in IMFDS which embody cognitive, affective, process, application and creativity variables, (3) students' achievement is high on cognitive, fairly good on attitude, high on process skill, high on application skill and low on creativity skill, (4) IMFDS is also influenced by psycho-social environment of science teaching and learning and teacher's competence. Psycho-social environment of science teaching and learning has a positive and significant influence (loading factor $=0.60, \mathrm{cr}=11.490$, and $\mathrm{p}<0.000 \mid$ ) but teacher's competence has not significant influence (loading $=0.34$, cr $=11.490$, and $\mathrm{p}<0.000 \mid$ ) on the process of developing instruction using IMFDS.
\end{abstract}

Key word: IMFDS, contextual approach, meaningful instruction 


\section{Pendahuluan}

Dengan diberlakukannya Undang-Undang Nomor 20 Tahun 2003 tentang Sistem Pendidikan Nasional dan Peraturan Pemerintah RI Nomor 19 Tahun 2005 tentang Standar Nasional Pendidikan. Serta dengan telah disusunnya buku panduan berdasarkan Permendiknas Nomor 22, 23 dan 24 Tahun 2006 yang merupakan acuan di dalam penyusunan Kurikulum Tingkat Satuan Pendidikan (KTSP). Maka diperlukan sebuah model implementasi kurikulum yang mengandung landasan konseptual pengembangan model yang mampu mengembangkan potensi siswa secara optimal, strategi pengorganisasian pembelajaran, dan asesmen yang relevan.

Model pembelajaran sains yang dilaksanakan di Indonesia serta berbagai pendekatan yang digunakannya selama ini tidak terlepas dari perkembangan global. Untuk memahami orientasi perkembangan pembelajaran sains perlu dilihat pula bagaimana sejarah perkembangan kurikulum yang diberlakukan pada saat itu dipengaruhi oleh perkembangan global. Oleh sebab itu, tahun 2000 pemerintah menerapkan kurikulum baru yang dinamakan Kurikulum Berbasis Kompetensi (KBK) yang kemudian disusul dengan diberlakukannya Kurikulum Tingkat Satuan Pendidikan (KTSP) sebagai kurikulum operasional pada tahun 2006. Namun demikian, kurikulum yang baik belum dapat memberikan jaminan untuk peningkatan kualitas pembelajaran. Komponen lain yang harus segera dibenahi adalah pendekatan atau metode pembelajaran yang tepat sesuai dengan karakteristik mata pelajaran masing-masing, kompetensi profesional guru sebagai ujung tombak di ruang kelas, media pembelajaran, lingkungan psikososial pembelajaran dan tidak kalah pentingnya adalah penilaian yang merupakan proses untuk mengetahui hasil atau dampak pembelajaran.

Perubahan kurikulum tentu saja membawa implikasi pada kegiatan belajar mengajar termasuk pada proses belajar mengajar sains. Oleh karena itu, pembelajaran sains harus diarahkan agar mampu untuk mencapai tujuan-tujuan tersebut di atas. Pembelajaran sains harus mampu mengembangkan hal yang lebih dari sekedar pengetahuan (knowledge), tetapi meliputi juga proses (processes), kreativitas (creativity), sikap atau tingkah laku (attitude), dan terapan (application). Hal ini sejalan dengan pendapat Yager \& McCormack (Yager, 1996, b: 3-4; 1992 b: 5-6), ada lima domain 
pembelajaran sains untuk pengajaran dan penilaian, yaitu domain konsep, proses, kreativitas, sikap, dan aplikasi.

Dengan mengacu pada beberapa permasalahan di atas, maka penelitian ini dimaksudkan untuk mengembangkan model 5 domain pembelajaran sains. Dalam pengembangan model tersebut dilakukan pendekatan yang terintegrasi antar berbagai aspek (metode, kompetensi guru, media, lingkungan psikososial pembelajaran) yang mungkin mempengaruhi keberhasilan proses belajar mengajar. Dengan demikian dalam penelitian akan dilihat pengaruh berbagai aspek tadi terhadap keberhasilan pencapaian siswa dalam mengambangkan kemampuan kognitif, afektif, psikomotorik, kreativitas dan kemampuan aplikasinya.

Pengembangan model ini diharapkan dapat mengisi kesenjangan antara teori dan muatan kurikulum KTSP dengan implementasi praktis di ruang kelas dalam bentuk pembelajaran nyata (real teaching), khususnya pada mata pelajaran sains di sekolah dasar. Rangkaian proses yang dilalui untuk mencapai tujuan dalam penelitian pengembangan ini antara lain:

1. Tujuan yang berkaitan dengan pengembangan dan impelementasi perangkat pembelajaran dan sumber belajar yang digunakan dalam pembelajaran 5 domain sains yang didesain dalam rancangan Penelitian dan Pengembangan (research and development). Tujuan ini dapat dirinci sebagai berikut:

a. Mengembangkan suatu model implementasi kurikulum berupa 5 domain sains yang dapat diakomodasi dalam pembelajaran sains di sekolah dasar.

b. Mengembangkan pembelajaran 5 domain sains sesuai dengan karakteristik isi pembelajaran khususnya pencapaian kompetensi sains di sekolah dasar.

c. Mengembangkan perangkat pembelajaran sains yang terdiri dari silabus, rancangan pembelajaran, media dan buku, agar dapat meningkatkan kualitas pembelajaran sains yang mengembangkan pembelajaran domain kognitif, afektif, proses, aplikasi dan kreativitas siswa di sekolah dasar. 


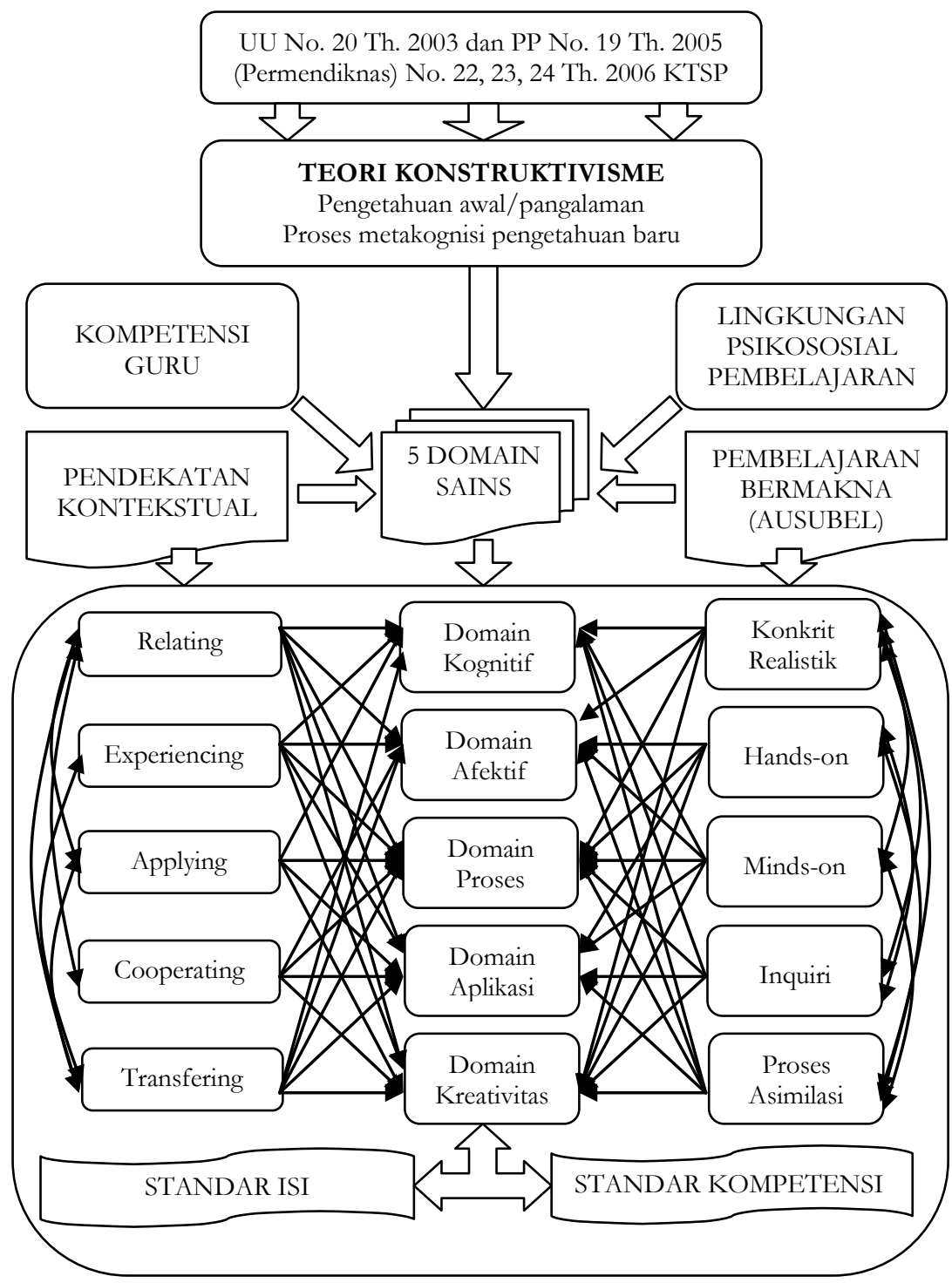

Gambar 1. Model Paradigmatik Pengembangan 5 Domain Pembelajaran Sains 
d. Mengimplementasikan teori konstruktivis dalam pembelajaran sains menggunakan pendekatan kontekstual agar dapat digunakan untuk peningkatan aktivitas hands-on dan minds-on siswa sehingga berdampak langsung pada pembelajaran 5 domain sains.

e. Mengembangkan asesmen yang mencakup 5 domain pembelajaran sains sehingga dapat memenuhi prinsip validitas isi, obyektivitas, keterbukaan, keholistikan, keintegratifan dan kebermaknaan menurut isi tujuan pembelajaran pencapaian kompetensi sains di sekolah dasar.

f. Menemukan prototipe dan prosedur pengembangan model 5 pembelajaran domain sains yang relevan dengan implementasi kurikulum sains di sekolah dasar.

2. Menemukan suatu model implementasi kurikulum berupa 5 domain pembelajaran sains menggunakan pendekatan kontekstual yang efektif untuk mengembangkan kognitif, afektif, proses, aplikasi dan kreativitas sesuai dengan standar kompetensi dan standar isi mata pelajaran sains sekolah dasar. Kemudian secara empiris dapat diketahui efektivitas implementasi dari model 5 domain pembelajaran sains, yang diperoleh dengan menggunakan desain penelitian dan pengembangan ( $R \& D)$ ini. Terkait dengan ini, maka rumusan tujuan dari penelitian ini dijabarkan menjadi:

a. Menemukan pola hubungan antar variabel dalam 5 domain pembelajaran sains, yaitu antara domain proses, domain sikap, dan domain aplikasi dengan domain pengetahuan dan domain kreativitas.

b. Menemukan pola hubungan antara lingkungan psikososial pembelajaran sains dan kompetensi guru sains dengan hasil 5 pembelajaran domain sains (pengetahuan, sikap, aplikasi, proses dan kreativitas).

Dalam rangka memperoleh gambaran tentang hal-hal yang menjadi fokus kajian dan rencana penelitian yang akan dilaksanakan, maka perlu kajian pustaka yang mendukung. Model yang dimaksud dalam penelitian ini, merupakan abstraksi atau simplifikasi dari dunia nyata, menyatakan tentang hubungan fungsional yang langsung maupun tidak langsung, 
interaksi dan interdependensi antara satu unsur dengan lainnya yang membentuk suatu sistem (Nasendi dan Anwar, 1985). Perbedaan mendasar dari MP5DS dengan terminologi model pembelajaran lainnya, terletak pada pengembangan perencanaan, perangkat, pendekatan, dan penilaian yang didesain untuk dapat mengukur ke lima domain pembelajaran sains tersebut secara keseluruhan dan sekaligus mengukur faktor lain yang mempengaruhinya yaitu kompetensi professional guru dan lingkungan psikososial pembelajaran sains.

Model pengembangan 5 domain sains adalah abstraksi dari suatu sistem atau fenomena yang ada dalam suatu kegiatan belajar mengajar khususnya dalam pembelajaran sains, mulai dari perencanaan, prosedur pelaksanaan, dan penilaian yang diformulasikan dalam bentuk kombinasi hubungan persamaan dan pertidaksamaan. Teori-teori tentang pendidikan khususnya tentang pembelajaran sains, yang dalam penelitian ini adalah implementasi pendekatan kontekstual yang mengacu pada teori konstruktivisme, serta pengalaman empiris yang relevan digunakan sebagai dasar untuk menformulasikan model yang cukup sederhana dan realistis, sehingga dapat dihasilkan pembelajaran bermakna.

Pembentukan model pengembangan 5 domain sains dimulai dari identifikasi masalah aktual yang terjadi. Model yang dibangun ini diarahkan untuk dapat memberikan solusi optimal dalam mengatasi permasalahan dalam bidang pembelajaran sains sehingga mampu menghasilkan pembelajaran yang bermakna. Tahapan pembentukan model disajikan pada Gambar 2.

Landasan psikologis dalam pembelajaran menggunakan Model Pembelajaran 5 Domain Sains ini terutama berkaitan dengan psikologi perkembangan peserta didik dan psikologi belajar. Psikologi perkembangan diperlukan terutama dalam menentukan isi/materi pembelajaran sains yang diberikan kepada siswa agar tingkat keluasan dan kedalamannya sesuai dengan tahap perkembangan peserta didik. Psikologi belajar memberikan kontribusi dalam hal bagaimana isi/materi pembelajaran sains tersebut disampaikan kepada siswa dan bagaimana pula siswa harus mempelajarinya. 


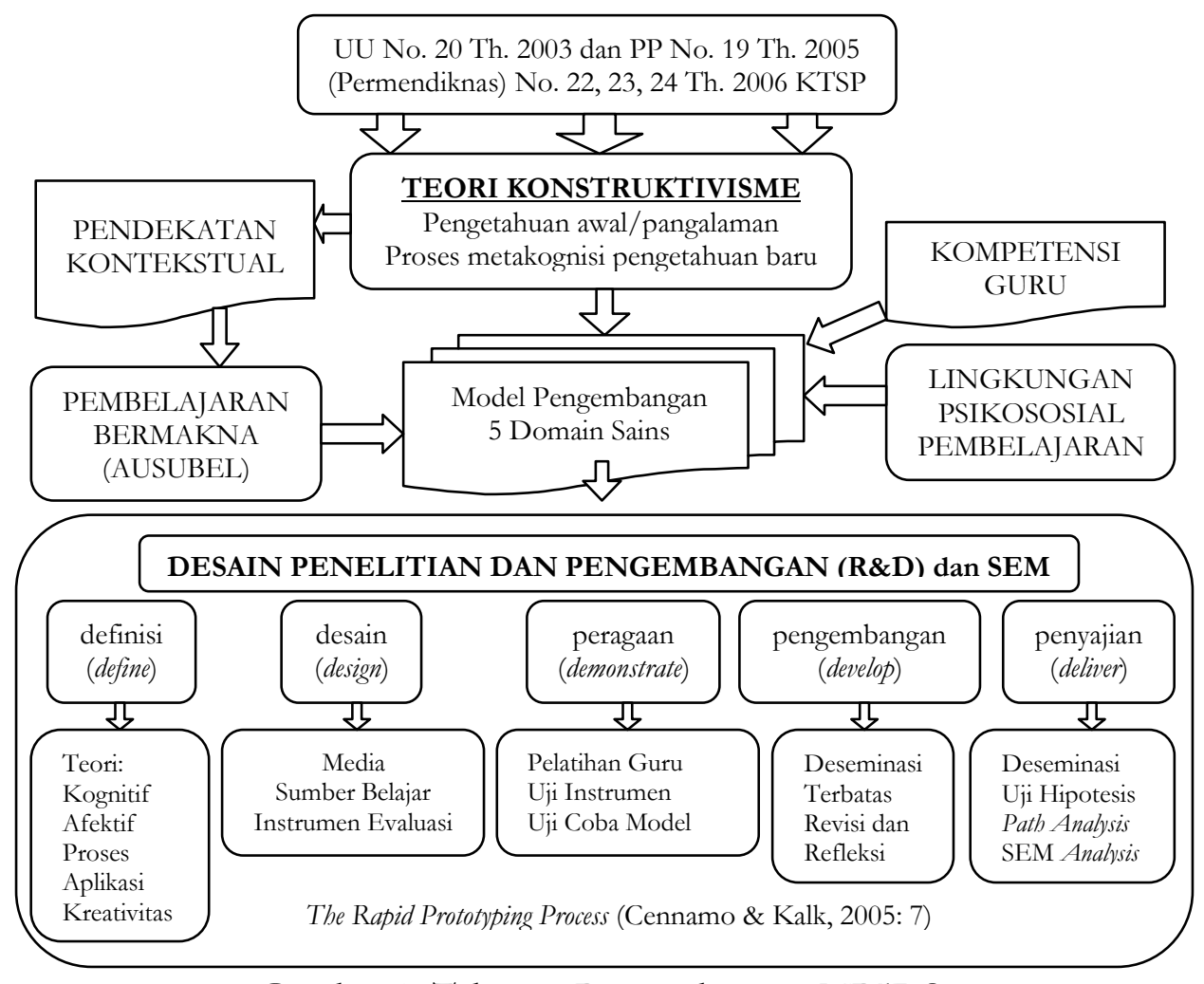

Gambar 2. Tahapan Pengembangan MP5DS

Sedangkan landasan filosofis pengembangan model adalah teori konstruktivisme. Teori ini bertitik tolak dari pandangan behaviorisme yang menpelajarai perubahan tingkah laku sampai kepada kognitivisme yang mempelajari tentang cara manusia belajar dan memperoleh pengetahuan. Dengan bantuan struktur kognitifnya, subyek menyusun pengertian realitasnya. Interaksi kognitif akan terjadi sejauh realitas tersebut disusun melalui struktur kognitif yang diciptakan oleh subyek itu sendiri. Struktur kognitif senantiasa harus diubah dan disesuaikan berdasarkan tuntutan lingkungan dan organisme yang sedang berubah (Piaget, 1988: 60). 
Konsep konstruktivisme melalui pembelajaran kontekstual diharapkan bisa menjadi proses yang lebih luas bagi pengembangan pemahaman siswa, sehingga mereka mampu terlibat dalam proses higherorder thinking. Melalui pendekatan kontekstual ini diharapkan akan terjadi pembelajaran bermakna. Karena salah satu teori belajar yang bersifat konstruktif adalah teori belajar bermakna dari Ausubel karena menekankan proses asimilasi dan asosiasi fenomena, pengalaman, dan fakta baru ke dalam konsep atau pengertian yang sudah dimiliki siswa sebelumnya.

Pada akhirnya keberhasilan sebuah model pembelajaran tentu akan dipengaruhi juga oleh faktor kompetensi guru dan lingkungan psikososial pembelajaran. Menurut Muhibbin Syah (2000: 230), kompetensi guru adalah kemampuan seorang guru dalam melaksanakan kewajibankewajibannya secara bertanggung jawab dan layak. Jadi kompetensi profesional guru dapat diartikan sebagai kemampuan dan kewenangan guru dalam menjalankan profesi keguruannya. Sedangkan yang dimaksud dengan lingkungan psikososial pembelajaran di kelas pada penelitian ini adalah, suasana batin (kejiwaan) dan sosial yang tercipta di dalam suatu kelas, yang dipandang dari persepsi para siswa dan guru di kelas tersebut.

\section{Metode Penelitian}

Karena penelitian ini diarahkan pada pengujian model melalui pengembangan suatu produk pendidikan dan berupaya menemukan pengetahuan baru yang berkenaan dengan fenomena yang bersifat fundamental, serta praktik pendidikan, maka digunakan metode penelitian dan pengembangan (research and development). Dalam pelaksanaan R \& D ini ada beberapa metode yang digunakan, yaitu: deskriptif, evaluatif, dan eksperimental. Metode penelitian deskriptif, digunakan dalam penelitian awal untuk menghimpun data tentang kondisi yang ada. Metode penelitian evaluatif, digunakan untuk mengevaluasi proses uji coba pengembangan suatu produk. Metode penelitian eksperimen digunakan untuk menguji keampuhan dari produk yang dihasilkan.

Beranjak dari pertimbangan pendekatan sistem bahwa pengembangan model pembelajaran tidak akan terlepas dari konteks 
pengelolaan, pengorganisasian belajar, dan pengembangan asesmen maka dipilih model spiral sebagaimana yang direferensikan oleh Cennamo dan Kalk (2005: 6). Dalam model spiral ini dikenal 5 (lima) fase pengembangan yakni: (1) definisi (define), (2) desain (design), (3) peragaan (demonstrate), (4) pengembangan (develop), dan (5) penyajian (deliver). Proses pengembangan berlangsung mengikuti gerak secara siklus iteratif (iterative cycles) dari visi definisi yang samar menuju kearah produk yang konkrit yang teruji efektivitasnya, sebagaimana yang direferensikan oleh Dorsey, Goodrum, \& Schwen, 1997 (Cennamo \& Kalk, 2005:7) yang dikenal dengan "the rapid prototyping process".

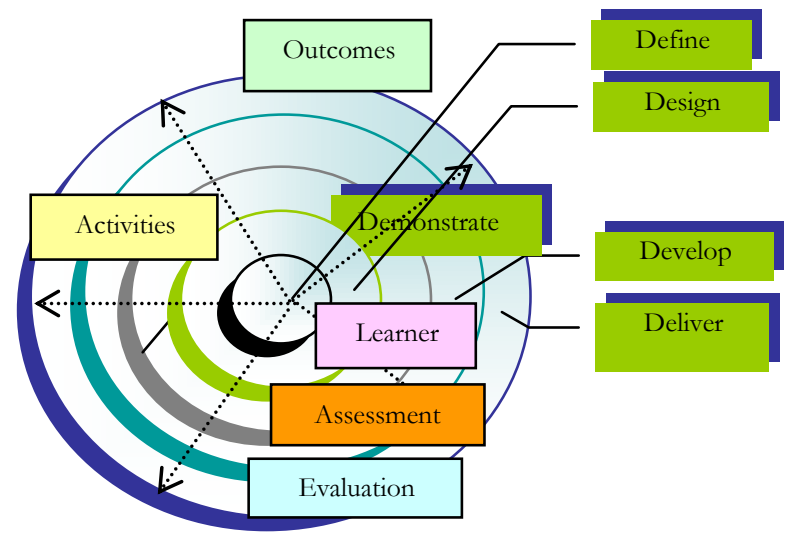

Keterangan:

Menunjukkan fase-fase pengembangan
Menunjukkan arah proses pengembangan

Gambar 3. Lima Fase Perancangan Pengajaran Model Spiral Diadaptasi dari 'Five Phases of Instructional Design' dari Cennamo dan Kalk (2005: 6)

Metode penarikan sampel yang dipakai yaitu random sampling. Jumlah sampel yang dibutuhkan untuk pengujian model dengan analisis SEM menurut Ferdinand (2002) tergantung pada jumlah parameter yang digunakan dalam seluruh variabel latent, yaitu jumlah parameter dikalikan 5 sampai 10. Dalam penelitian ini sampelnya adalah 496 siswa dan 21 guru dari 21 sekolah dasar. Diagram alur pengembangan model digambarkan pada gambar 4. 


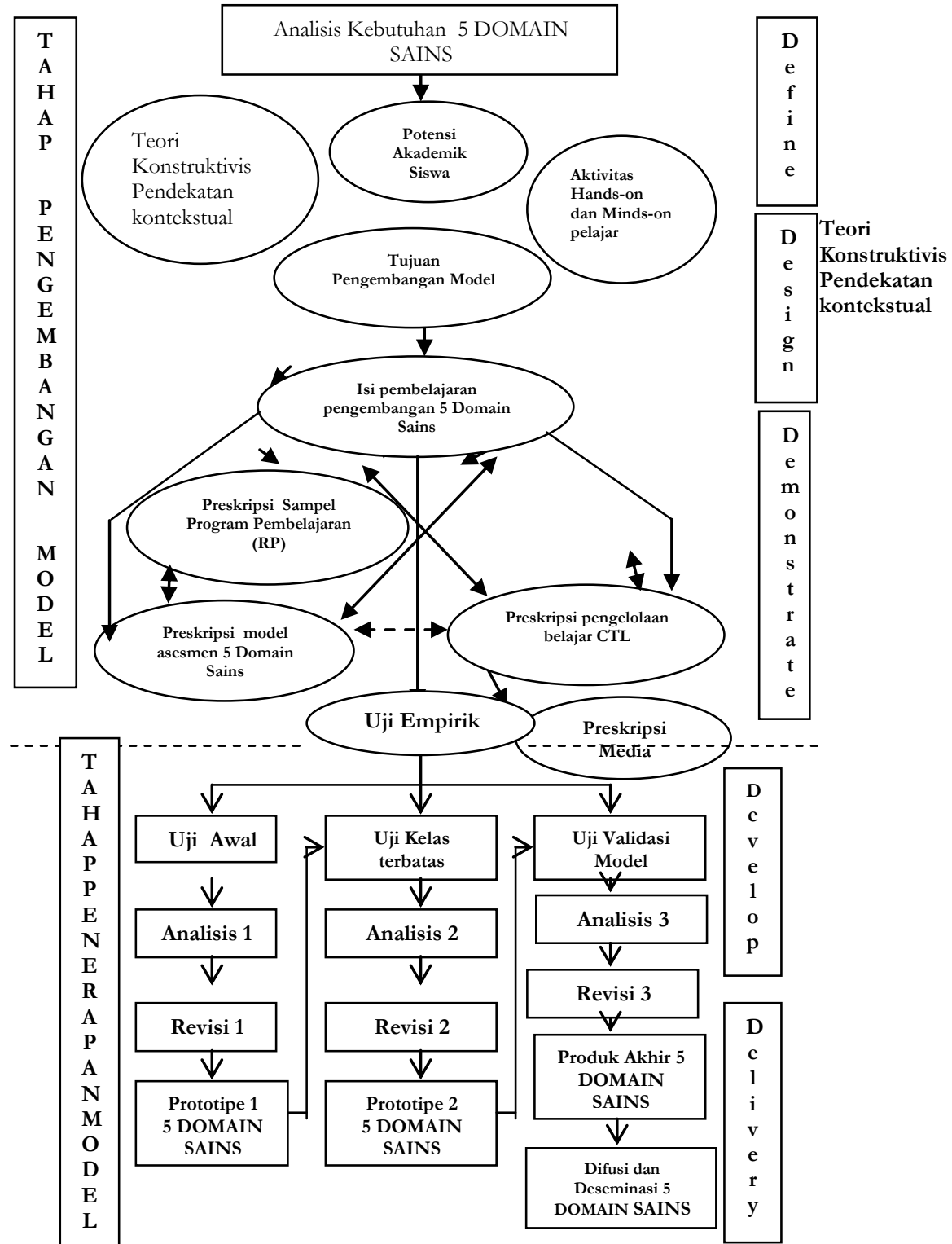

Gambar 4. Diagram Alir Prosedur Pengembangan Model Pembelajaran 5 Domain Sains dengan Pendekatan Kontekstual

Model Pembelajaran Lima Domain Sains dengan Pendekatan Kontekstual - 278 
Selanjutnya data hasil pengujian yang merupakan implementasi produk berupa model pembelajaran di ruang kelas selanjutnya dianalisis dengan menggunakan analisis jalur dan model persamaan struktural. Data yang diperoleh (berupa skor hasil penerapan instrumen untuk domain pemahaman, proses, sikap, aplikasi dan kreativitas) pada saat menerapkan model pengembangan 5 domain sains di kelas pembelajaran pertama kali dianalisis dengan analisis jalur (Kerlinger, 2002: 990).

Ada lima variabel yang dijadikan objek penelitian, tiga variabel eksogenus yaitu domain proses, domain sikap, dan domain aplikasi, serta dua variabel endogenus yaitu domain kognitif dan domain kreativitas. Domain kognitif menjadi variabel mediasi antara domain proses, domain aplikasi dan domain sikap dengan domain kreativitas. Analisis berikutnya menggunakan stuctural equation modelling (SEM) untuk pengujian model pengembangan lima domain sains dengan variabel-variabel yang mempengaruhinya yaitu lingkungan psikososial pembelajaran sains dan kompetensi guru dengan menggunakan model development strategy, sebuah model diusulkan lalu diestimasi.

Pengolahan data hasil penelitian menggunakan software AMOS 6.0. under Windows. Untuk menguji hipotesis yang dibangun diperlukan pengamatan terhadap output yang dihasilkan, terutama pada regression weights. Hubungan dan signifikansi antara variable yang dibangun dalam model dapat ditentukan melalui critical ratio (CR)-nya. Critical ratio ini merupakan t hitung.

\section{Hasil Penelitian dan Pembahasan}

Sesuai dengan tujuan dari penelitian ini, yaitu untuk mengembangkan pembelajaran 5 domain sains yang dilengkapi perangkat pembelajaran dan asesmen dengan pendekatan kontekstual untuk mengembangkan pembelajaran yang bermakna bagi siswa, maka telah didapatkan beberapa hasil dari pengembangan model dan pengujian hipotesis, sebagai berikut:

1. Deskripsi masing-masing variabel 5 domain sains menunjukkan hasil sebagai berikut; 
a. Rata-rata siswa dapat menyelesaikan $73,11 \%$ tes kognitif yang diberikan, hal ini menunjukkan bahwa siswa memiliki tingkat pencapaian yang tinggi (rentang 60\% sampai dengan 79,99\%).

b. Rata-rata siswa memiliki sikap yang cukup baik nilai 2,54 dari maksimum 5 atau 58\% (tingkat pencapaian berada pada rentang 40\% sampai dengan $59,99 \%$ ) terhadap proses belajar mengajar menggunakan 5 DOMAIN SAINS.

c. Rata-rata siswa mendapatkan nilai proses dengan menggunakan lembar observasi adalah 63,31 (63,31\%). Hasil ini berada pada rentang kategori pencapaian tinggi $(60 \%$ sampai dengan $79,99 \%)$. Sedangkan nilai ratarata penilaian fortofolio yang diperoleh siswa adalah 50,58\%. Hasil ini berada pada rentang kategori pencapaian cukup tinggi (40\% sampai dengan 59,99\%).

d. Tingkat pencapaian siswa untuk domain aplikasi adalah 61,93, termasuk dalam kategori tinggi (rentang 60\% sampai dengan 79,99\%).

e. Rerata pencapaian siswa untuk penilaian kreativitas menggunakan fortofolio adalah 39,41 (tingkat pencapaian rendah ada pada rentang $20 \%$ sampai dengan 39,99\%), nilai rerata tes pemecahan kasus 37,13 (tingkat pencapaian rendah ada pada rentang 20\% sampai dengan $39,99 \%$ ), dan nilai rerata tes penalaran figural 5,58 (tingkat pencapaian cukup tinggi ada pada rentang 40\% sampai dengan 59,99\%). Hasil ini menunjukkan bahwa kreativitas siswa belum mencapai tingkat yang diharapkan, dan masih memerlukan stimulus yang berupa aktivitasaktivitas nyata dengan melibatkan aktivitas hands-on dan minds-on.

f. Nilai rerata kuisioner lingkungan psikososial pembelajaran sains yang direspon oleh siswa adalah $2.94(58,8 \%)$ dari nilai total 5, hal ini menunjukkan bahwa respon siswa memiliki kategori cukup baik berada pada rentang $40 \%$ sampai dengan $59,99 \%$.

g. Nilai rerata kompetensi yang dicapai oleh guru adalah 3,25 (65\%) dari nilai total 5 , hal ini menunjukkan bahwa kompetensi guru memiliki kategori tinggi berada pada rentang 60\% sampai dengan 79,99\%. Hal ini menunjukkan telah berjalannya fungsi pelatihan dan pendampingan yang dilakukan selama kegiatan penelitian ini berlangsung. 
2. Telah dapat dikembangkan suatu model implementasi kurikulum berupa pembelajaran 5 domain sains yang dapat diakomodasi dalam pembelajaran sains di sekolah dasar, yang sesuai dengan karakteristik isi tujuan pembelajaran khususnya pencapaian kompetensi sains di sekolah dasar. Model ini mengunakan pendekatan kontekstual agar dapat digunakan untuk peningkatan aktivitas hands-on dan minds-on siswa sehingga berdampak langsung pada pengembangan kognitif, afektif, sikap, proses dan kreativitas.

3. Telah dilakukan pengujian hipotesis tentang hubungan antar variabel dalam 5 domain sains, yaitu antara domain proses, domain sikap, dan domain aplikasi dengan domain pengetahuan dan domain kreativitas. Pengujian hipotesis ini menggunakan analisis jalur (path analysis) untuk menguji hubungan antar variabel dalam 5 domain sains dengan struktur jalur sebagai berikut:

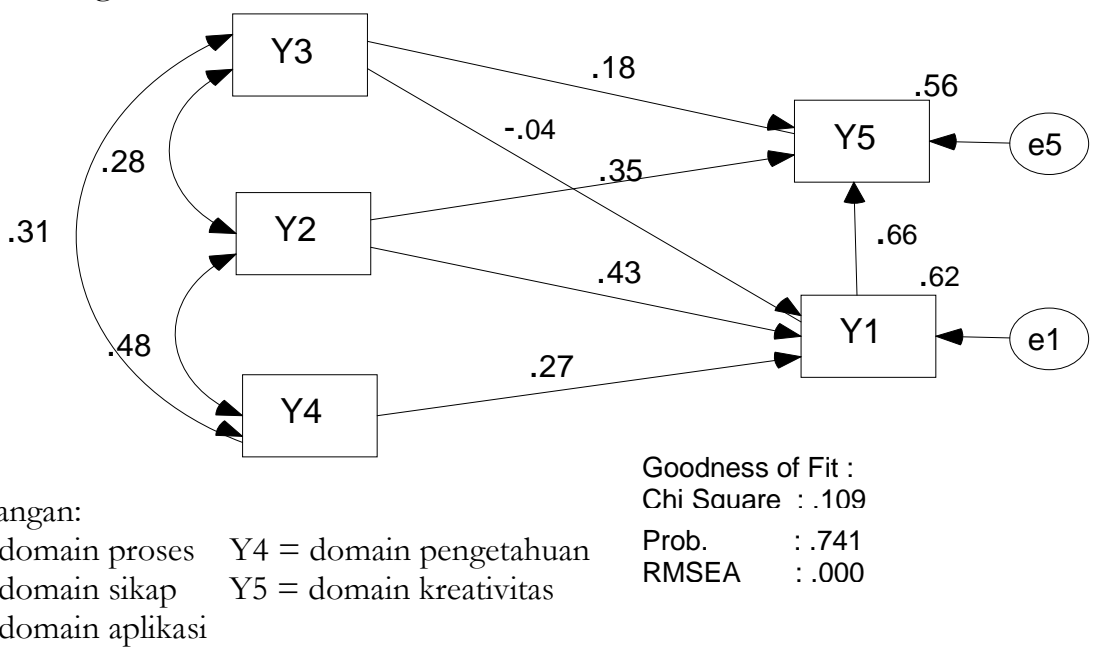

Gambar 5. Diagram Path untuk Analisis Jalur Variabel 5 Domain Sains

Berdasarkan hasil pengujian statistik mengenai Goodness of fit, dapat dilihat bahwa nilai chi-square sebesar 0,109 mendekati 0 dengan $\mathrm{p}=0.741>$ 
0.05 , GFI $=0.995>0.90$, RMSEA $=0.00<0.08$, CFI $=0.997>0,95$, dan TLI $=0.991>0,95$, yang berarti seluruhnya memenuhi nilai kritis yang ditetapkan. Hasil ini menunjukkan bahwa semua kriteria memenuhi nilai kritis, yang berarti model sesuai dengan data, sehingga layak untuk digunakan.

4. Telah dilakukan pengujian hipotesis tentang hubungan antar variabel 5 domain sains dengan variabel yang mempengaruhinya. Pengujian hipotesis ini menggunakan model persamaan struktural untuk menguji hubungan antar variabel 5 domain sains dengan variabel lingkungan psikososial pembelajaran dan kompetensi guru.

Tabel 1. Hasil Pengujian Goodness of Fit Tahap Awal

\begin{tabular}{|l|c|c|c|}
\hline Goodness of Fit & Hasil & Nilai Kritis & Keterangan \\
\hline Chi Square & 886,664 & Kecil & \multirow{2}{*}{ Kurang Baik } \\
\cline { 1 - 2 } Probability & 0,00 & $\geq 0,05$ & \\
\hline GFI & 0,818 & $\geq 0,90$ & Kurang Baik \\
\hline RMSEA & 0,136 & $\leq 0,08$ & Kurang Baik \\
\hline AGFI & 0,833 & $\geq 0,90$ & Kurang Baik \\
\hline CFI & 0.833 & $\geq 0,95$ & Kurang Baik \\
\hline TLI & 0,798 & $\geq 0,95$ & Kurang Baik \\
\hline
\end{tabular}

Hasil pengujian ini menunjukkan bahwa goodness of fit tidak memenuhi kriteria nilai kritis yang ditetapkan. Hal ini dapat dilihat bahwa dari seluruh kriteria yang digunakan menunjukkan adanya hasil yang kurang baik, yang berarti bahwa model tidak layak digunakan. Hasil ini selanjutnya dimodifikasi dengan petunjuk modification indices covarians antar error indikator dengan diawali memilih MI yang paling besar diantara modifikasi lainnya yang harus dilakukan, karena dengan MI yang paling besar diharapkan terjadi penurunan nilai Chi Square yang cukup berarti dan kenaikan probabilitas error yang cukup berarti pula sampai model tersebut fit. Hasilnya seperti tampak dalam Gambar 6: 


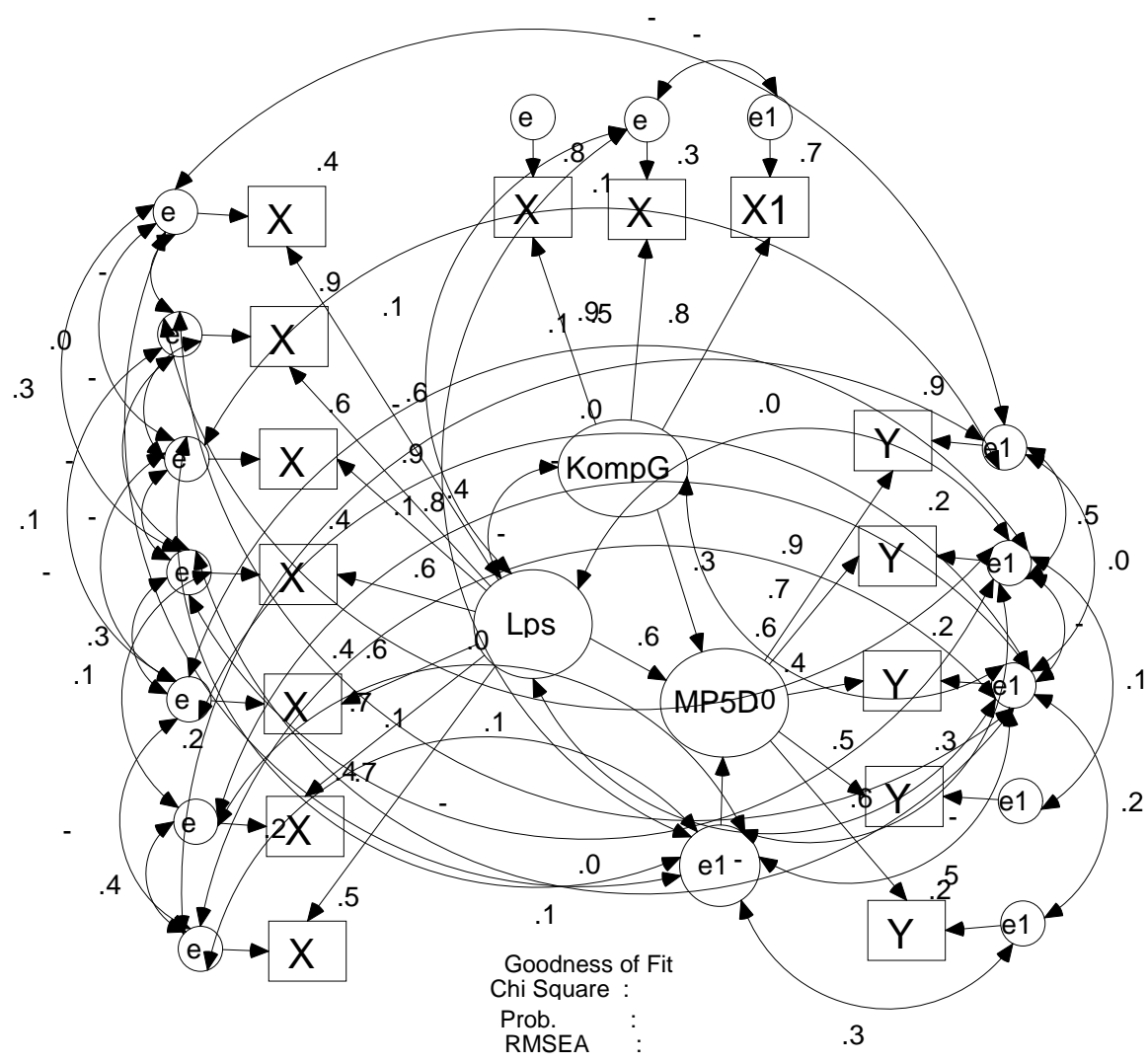

Gambar 6. Model Persamaan Struktural 5 Domain Sains

Hasil Modifikasi Indeks

Keterangan:

KompGu = variabel kompetensi guru

MP5DS $=$ model yang dikembangkan

Lpsi $=$ variabel lingkungan psikososial

$\mathrm{Y} 1=$ domain pengetahuan

$\mathrm{Y} 2=$ domain sikap

$\mathrm{Y} 3=$ domain proses

$\mathrm{X} 2=$ dukungan guru

$\mathrm{X} 4=$ kegiatan penyelidikan

$\mathrm{X} 6=$ kerja sama siswa

$\mathrm{X} 8=$ kompetensi mengajar

$\mathrm{X} 10=$ kompetensi memotivasi

$$
\begin{aligned}
\mathrm{e} & =\text { error (unic factor) } \\
\mathrm{Y} 4 & =\text { domain aplikasi } \\
\mathrm{Y} 5 & =\text { domain kreativitas } \\
\mathrm{X} 1 & =\text { kekompakan siswa } \\
\mathrm{X} 3 & =\text { keterlibatan siswa } \\
\mathrm{X} 5 & =\text { arahan tugas } \\
\mathrm{X} 7 & =\text { kesetaraan } \\
\mathrm{X} 9 & =\text { kompetensi praktek }
\end{aligned}
$$


Hasil ini menunjukkan pola hubungan antara variabel yang terdapat dalam 5 domain sains sebagai berikut:

a. Terdapat hubungan langsung positif dan signifikan antara lingkungan psikososial pembelajaran sains dengan hasil pembelajaran 5 domain sains. Terlihat dari nilai koefisien jalur sebesar 0,60 antara LPsi da MP5DS.

b. Tidak terbukti adanya hubungan langsung positif yang signifikan antara kompetensi guru dengan hasil pembelajaran 5 domain sains. Terlihat dari nilai koefisien jalur sebesar 0,34 antara variable KompGu dan MP5DS.

\section{Simpulan}

Bukti-bukti empirik hasil pengujian 5 domain sains lengkap dengan perangkat pembelajaran, strategi pengorganisasian pembelajaran, asesmen yang dirancang, serta variabel yang mempengaruhinya yaitu kompetensi guru dan lingkungan psikososial pembelajaran sains, telah disimpulkan dapat digunakan untuk mengoptimalkan pencapaian standar kompetensi dan standar isi sesuai dengan K'TSP. Berdasar pada hasil uji empirik ini, maka saran ditujukan untuk uji model pengembangan lebih lanjut pada kawasan yang lebih luas melalui deseminasi model oleh pihak lain. Dalam rangka implementasi kurikulum KTSP khususnya dalam bidang sains perlu dipertimbangakan untuk menerapkan 5 domain sains karena secara teoritis dan praktis telah dapat mengembangkan pembelajaran multidomain yang dimiliki siswa. Penelitian ini menghasilkan: (1) prototipe perangkat pembelajaran dan prosedur implementasi MP5DS untuk pembelajaran sains, (2) dapat diuji pengaruh langsung yang positif dan signifikan maupun tidak langsung antar variabel kognitif, afektif, proses, aplikasi dan kreativitas, (3) peningkatan pencapaian nilai tes kognitif, sikap, proses, aplikasi dan nilai kreativitas yang secara umum meningkat secara signifikan, dan (4) pengaruh dari lingkungan psikososial pembelajaran sains dan kompetensi guru terhadap MP5DS. Model ini telah memberikan gambaran nyata tentang bagaimana suatu konsep kurikulum dapat diimplementasikan sesuai dengan landasan teorinya yaitu konstruktivisme. Di samping itu 
ditinjau dari aspek kelayakan model, baik ditinjau dari segi pembiayaan yang relatif murah karena media dapat dibuat sendiri oleh warga sekolah dari bahan daur ulang, maupun relevansinya dengan standar isi dan standar kompetensi, maka model ini memiliki visibilitas yang tinggi untuk diterapkan dalam pembelajaran nyata (real teaching).

\section{Daftar Pustaka}

Cennamo, K. and Kalk, D. (2005). Real World Instructional. Design. From Thompson Learning. Available at UT-Coop and. www.amazon.com.

Ferdinand, A. (2000). Structural equation modelling dalam peneltian manajemen. Semarang: Seri Pustaka Kunci 03/BP UNDIP.

Kerlinger, F. N. (2002). Asas-asas penelitian behavioral. Terjemahan Simatupang, L.R. New York : Holt Rinehart \& Winston.

Nasendi, B. D. \& Anwar, A. (1985) Program linear dan variasinya. Jakarta: Gramedia.

Piaget. J. (1988). Antara tindakan dan pikiran. (Terjemahan Agus Cremers). Jakarta: PT. Rineka Cipta.

Syah, M. (2000). Psikologi pendidikan dengan pendekatan baru. Bandung: Remaja Rosdakarya.

Yager, R. E., \& McCormack, A. J. (1989). Assessing Teaching/Learning Successes in Multiple Domains of Science and Science Education. Science Education, 3(1), 45-58. 